\title{
Efficiency of Different Application Techniques of Three Neonicotinoids Insecticides against Florida Wax Scale, Ceroplastes floridensis Comstock and Its Parasitoid, Coccophagus scutellaris (Dalman)
}

\author{
Darwish, A. A. E.; A. M. H. Khozimy; M. M. R. Attia and M. A. F. Abuzeid \\ Plant protection department, Faculty of Agriculture, Damanhour University, Egypt
}

Received: $5 / 10 / 2020$

\begin{abstract}
Field experiments were conducted to evaluate the efficiency of three different application techniques of three neonicotinoids insecticides against the Florida wax scale (FWS), Ceroplastes floridensis Comstock (Hemiptera: Coccidae) and its parasitoid, Coccophagus scutellaris (Dalman). The experiments were achieved in a private farm at Nobaria district, Beheira Governorate, Egypt during the spring seasons of 2019 and 2020. For ten weeks, the leaves samples were taken weekly. The results show that, among the different methods of insecticide applications, trunk injection technique achieved the highest reduction percentages for both adults and nymphs stages of FWS, followed by soil drench and finally foliar spray technique. However among different methods of application, trunk injection application maintained more C. scutellaris population (low reduction percentages \%) than the two other methods (soil drench and foliar spray). In another hands, among insecticides, imidacloprid was the most effective and caused significant reduction in the population of the FWS and its parasitoid followed by acetamiprid and finally dinotefuran. Therefore, these results concluded that the trunk injection was the most appropriate technique for control $C$. floridensis and could be recommended in integrated pest management programs.
\end{abstract}

Keywords: Trunk injection, soil drench, foliar spray, neonicotinoids insecticides, Ceroplastes floridensis

\section{INTRODUCTION}

Florida wax scale, Ceroplastes floridensis Comstock (Hemiptera: Coccidae) is one of the most dangerous citrus pests (Ben-Dov, 1993; Eserkaya and Karaca, 2016; Zaki, et al., 2019). The different stages of this insect feed on the leaves and twigs of its hosts. Severe infestation leads to dropping of leaves and drying the twigs. The parasitoid, Coccophagus scutellaris (Dalman) (Hymenoptera: Aphelinidae) is a cosmopolitan parasitoid of various species of soft scale insects including C. floridensis (Rosen, 1967; Nikol'skaja, 1952; Abd-Rabou, 2001). Chemical control of scale insects is relatively difficult, because the waxy layer which cover and protect them from contact insecticides. (Radwan, 2003; Elekçioğlu and Şenal, 2007; Abo-Shanab, 2012; Siam and Othman, 2020). Furthermore many studies show that the conventional application methods of chemical insecticides such as foliar spray are relatively inefficient techniques of delivering insecticides to their target. The deposited of solution of the applied spray on the tree canopy ranged from 29 to $56 \%$ of the total solution. The remaining product wasted, either to drift, run off, or because it can not be applied precisely to where it is needed. (Perry et al., 1991; Zhu et al., 2006). Despite of the rapidly evolved of the insecticides groups which used in fruit production, the application techniques of these insecticides have changed very little (VanWoerkom, 2012). Trunk injection is a method of target precise application of insecticides. The trunk injection system directly injects the insecticides into the trees vascular system without exposed it to the environment conditions. As compared with traditional methods (such as foliar sprays) the trunk injection which also known stem injection is relatively simple, quick and require less active ingredient (Norris 1965; Doccola et al. 2009;
VanWoerkom, 2012; Doccola and Wild, 2012; Bhandari and Cheng, 2016). Soil drench methods involve placing insecticides in liquid formulation near the roots in the soil for root uptake. Keeping in view the above mentioned facts, the objective of this work was to evaluate the efficacy of different applications techniques of three neonicotinoid insecticides against FWS, C. floridensis and its parasitoid C. scutellaris in navel orange trees (Citrus sinensis L.).

\section{MATERIALS AND METHODS}

The study was carried out in a private farm of navel orange Citrus sinensis (L.) grafted on Rangpur lime (Citrus limonia L. Osbeck) at Nubaria district, Beheira Governorate, Egypt during two consecutive seasons, 2019 and 2020. The trees were 15 years old and spaced 5 by $5 \mathrm{~m}$ apart. Three different application techniques of the selected insecticides (acetamiprid, imidacloprid, dinotefuran) were evaluated against the citrus wax scale, C. floridensis and its parasites, $C$. scutellaris.

The methods of applications of the selected insecticides:

\section{Foliar spray}

The trees were sprayed with a rate of 5-6 liters / tree with conventional hand knapsack sprayer to ensure complete coverage of all parts of the trees with selected insecticides.

\section{Trunk injection}

The trunk injections were made with the help of a metal drill on approximately $25 \mathrm{~cm}$ of the average trees diameter (in areas of healthy and active wood), 30 $\mathrm{cm}$ above ground level and on a hole of $5 \mathrm{~cm}$ deep were bored into the trunk at an angle of $45^{\circ}$. The injection volume was made up to $10 \mathrm{ml}$ using tap-water 


\section{Soil drench}

Soil drenching was the processed of adding diluted insecticides directly to the soil at the base of the trees. The rate of application was of 5-6 liters of each tested insecticides dilution / tree. The specific (recommended) doses of the different insecticides were diluted with water in a container and drenched around the navel orange trees within $20-50 \mathrm{~cm}$ of the tree trunk and then the trees were irrigated.

\section{Insecticides:}

Tested insecticides trade names, percentage of active ingredients, formulation types and application rates are listed in Table 1. The insecticides concentrations used in this study were based on the labeled recommendation rate.

Table (1): Descriptions of the insecticides used against the Florida wax scale and its parasitoids.

\begin{tabular}{cccccc}
\hline $\begin{array}{c}\text { Active } \\
\text { ingredient }\end{array}$ & Trade Name & Rate & $\begin{array}{c}\text { (a.i.) \% and } \\
\text { formulation }\end{array}$ & $\begin{array}{c}\text { Recommended } \\
\text { rate }\end{array}$ & Manufacturer \\
\hline Acetamiprid & Mospilan ${ }^{\circledR}$ & $350 \mathrm{gm} . / \mathrm{Fad}$. & $20 \% \mathrm{SP}$ & $25 \mathrm{mg} \mathrm{L}^{-1}$ & Nippon Soda Ltd. \\
Dinotefuran & Ochin ${ }^{\circledR}$ & $25 \mathrm{gm} . / 100 \mathrm{~L}$ & $20 \% \mathrm{SG}$ & $50 \mathrm{mg} \mathrm{L}-1$ & Mitsui Chemicals \\
Imidaclopride & Confidor ${ }^{\circledR}$ & $30 \mathrm{~cm} / 100 \mathrm{~L}$ & $20 \% \mathrm{SC}$ & $0.5 \mathrm{ml} \mathrm{L-1}$ & Bayer CropScience \\
\hline
\end{tabular}

\section{Insects Count}

Randomly samples consisted of 100 leaves from each treatment were divided into two parts. The $1^{\text {st }}$ portion (ten leaves from each tree or replicate) was inspected before and weekly for 10 weeks post treatment. The scales were carefully examined under binocular microscope and the number of living and dead adult females and immature stages were recorded. Dead scales were discolored, shriveled, gradually fall off the leaves. Squishing the live scales will produce a liquid, while dead scales will be dry when crushed. In the $2^{\text {nd }}$ portion, after the examined of leaves, the sample scales were counted, the samples placed in glass jars and kept in the laboratory for securing any emerging parasitoids. For ten weeks, the samples were weekly taken. For each application technique, the efficiency of the insecticides as the general means of reduction percentages of the adults and nymphs of FWS and its parasite was calculated according to the formula of Henderson and Tilton (1955):

Reduction percentage $=100 *[1-(\mathrm{T} 2 \mathrm{R} 1 / \mathrm{T} 1 \mathrm{R} 2)]$ Where:

$\mathrm{R} 1=$ number of alive scales (or its parasite) before treatment in untreated plots.

$\mathrm{R} 2$ = number of alive scales (or its parasite) after treatment in untreated plots.

$\mathrm{T} 1$ = number of alive scales (or its parasite) before treatment in treated plots.

$\mathrm{T} 2=$ number of alive scales (or its parasite) after treatment in treated plots.

\section{Statistical analysis:}

The experiment was performed as a factorial in the form of Randomized Complete Block design (RCBD), with five replicates (trees) per treatment and untreated control (fifty trees). Water was used as control treatment. Data were subjected to the statistical analysis according to the technique of analysis of variance (ANOVA) as published by Gomez and Gomez (1984) by using "MSTAT-C" computer software package. Least significant of difference
(LSD) method was used to test the differences between treatment means at 5\% level of probability as described by Snedecor and Cochran (1980).

\section{RESULTS}

\section{Effect of application methods}

The results indicated that there are significant differences between the different application methods as well as among the insecticides treatments. As shown in Figs (1 - 6), the trunk injection technique was the most effective application method for combat both of adults and nymphs of $C$. floridensis by using each of imidacloprid, dinotefuran and acetamiprid. By using the imidacloprid, the trunk injection method led to reduction percentages of 82.34 and $84.73 \%$ for the adults of $C$. floridensis during the consecutive seasons, 2019 and 2020, respectively. While these percentages recorded 79.64 and $81.92 \%$ for the nymphs for the same seasons, respectively. On the other hand, the least effective method in combat this scale insect with imidacloprid was the foliar spray method (54.26 and $57.54 \%$ in $1^{\text {st }}$ season and 49.62 and $58.47 \%$ in $2^{\text {nd }}$ season for adults and nymphs, respectively). Statistically analysis of variance of data histogramatically illustrated in Figs. (3 and 4) revealed that the highest mortality rates of adults and nymphs of C. floridensis were achieved using the acetamiprid insecticide throughout trunk injection technique (73.27 and $76.03 \%$ in the $1^{\text {st }}$ season, 2019 and 73.69 and 76.7 in the $2^{\text {nd }}$ season, respectively). Otherwise, the foliar spray methods achieved the least reduction percentages of adults (45.36 and 43.49\%) and nymphs (49.87 and $52.75 \%$ ) during the two successive seasons. The same trends were observed by using the dinotefuran insecticide whereas the reduction percentages recorded 65.15 and $75.27 \%$ in the $1^{\text {st }}$ season and 67.47 and $71.92 \%$ in the $2^{\text {nd }}$ season of the adults and nymphs of C. floredensis when the trunk injection was applied. While the soil drench ranked the second and finally foliar spray method. 
To study the appropriate insecticide applied method against the populations of the parasitoids, $C$. scutellaris (Dalman), the reduction percentages of the parrasit, C. scutellaris population were compared. The results revealed that the most effective appropriate method (the lowest reduction percentages) was the trunk injection method (Figs 1-6). Statistically analysis of variance of data histogramatically illustrated in Figs (1 and 6) revealed that the foliar pray was the highly effective methods in reduction $C$. scutellaris. Therefore, this method is not recommended in the integrated pest management programs of $C$. floridensis.

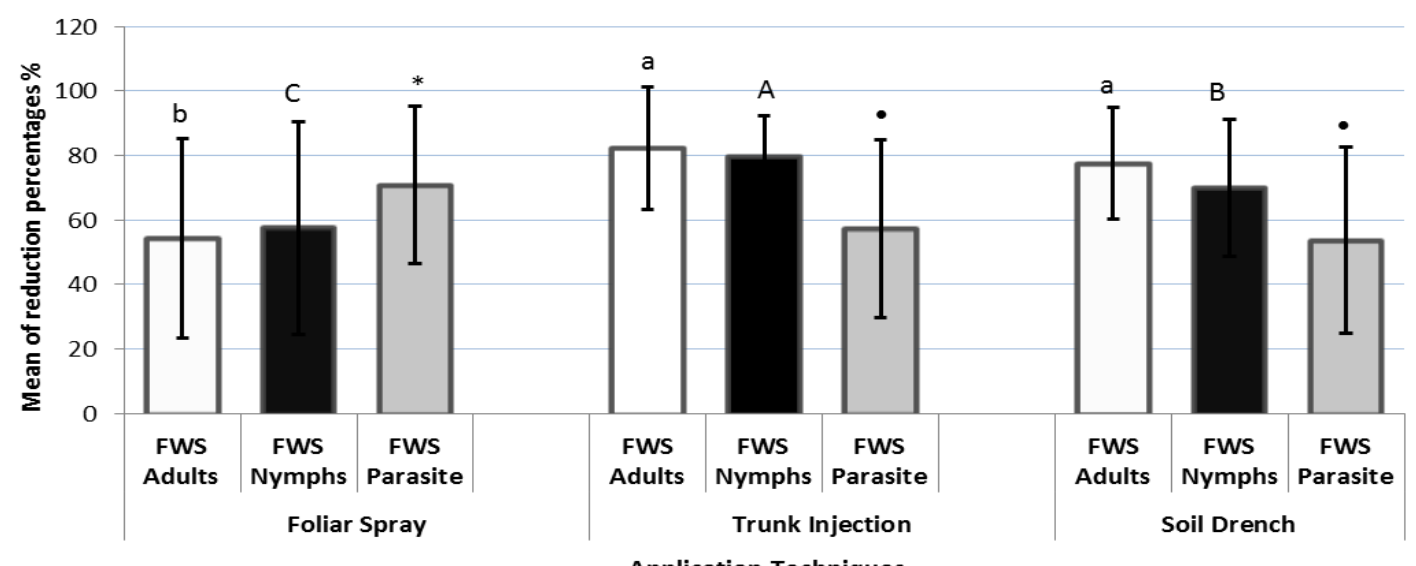

Fig. (1): The general means of reduction percentages of adults and nymphs of Florida wax scale (FWS) and its parasitoid by Imidacloprid insecticide throughout different application techniques in the $1^{\text {st }}$ season, 2019. ( $\mathrm{F}$ adult $=$ 21.016, df $=149$, L. S. D. =9.17095; F nymphs $=10.811$, df $=149$, L. S. D. $=9.41315 ;$ F parasite $=5.606, d f=149$, L. S. D. $=10.713)$

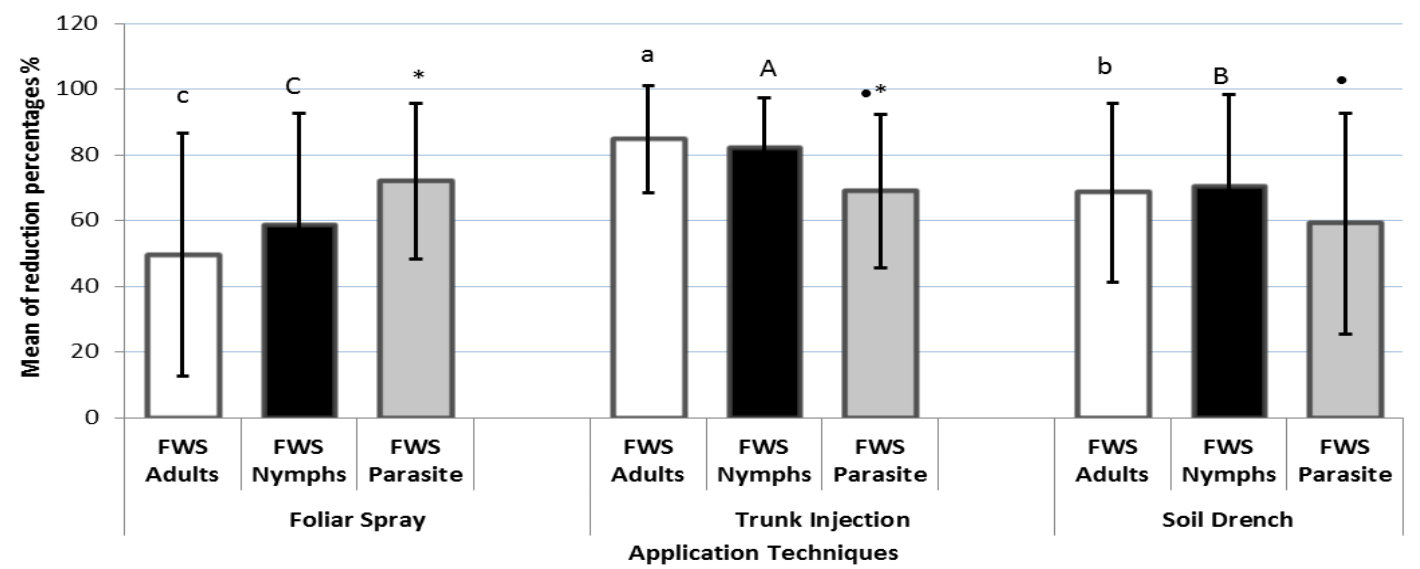

Fig. (2): The general means of reduction percentages of adults and nymphs of Florida wax scale (FWS) and its parasitoid by Imidacloprid insecticide throughout different application techniques in the $2^{\text {nd }}$ season, 2020. F adult $=$ 19.531, df $=149$, L. S. D. $=11.11245 \mathrm{~F}$ nymphs $=9.381, \mathrm{df}=149, \mathrm{~L} . \mathrm{S} . \mathrm{D} .=10.69875 \mathrm{~F}$ parasite $=3.061, \mathrm{df}=149, \mathrm{~L}$. S. D. $=10.77475$

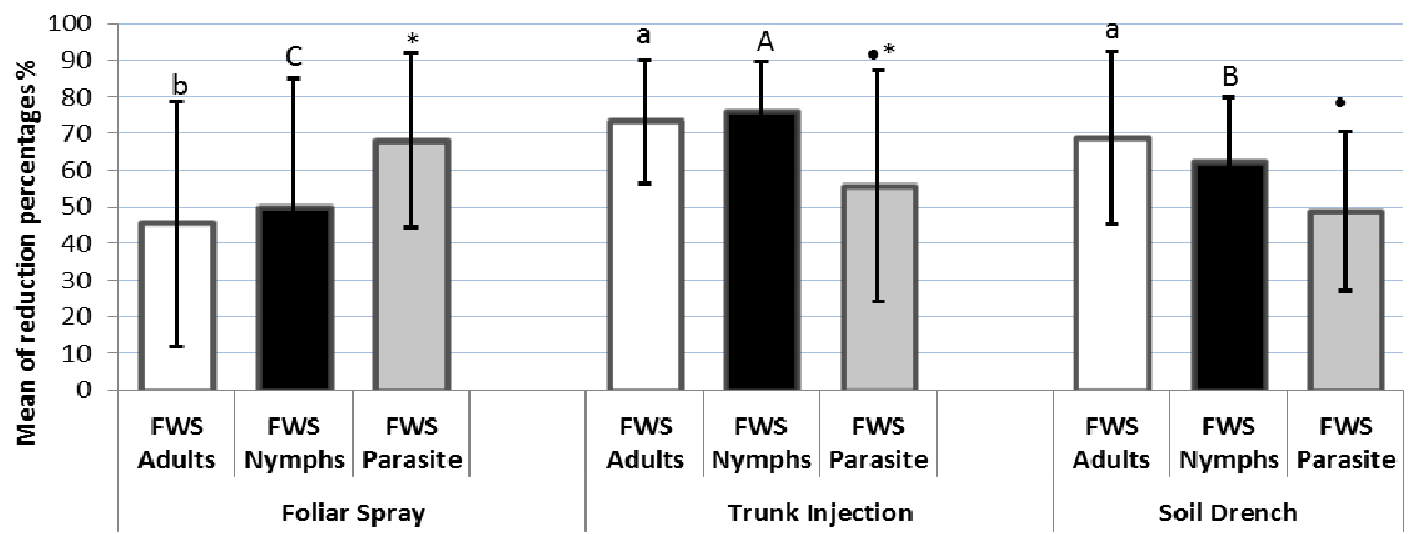

Application Techniques

Fig. (3): The general means of reduction percentages of adults and nymphs of Florida wax scale (FWS) and its parasitoid by acetamiprid insecticide throughout different application techniques in the $1^{\text {st }}$ season, 2019. F adult $=$ 17.190, df $=149$, L. S. D. $=10.09545 \mathrm{~F}$ nymphs $=14.779, \mathrm{df}=149$, L. S. D. $=9.52055 \mathrm{~F}$ parasite $=7.034, \mathrm{df}=149, \mathrm{~L}$. 


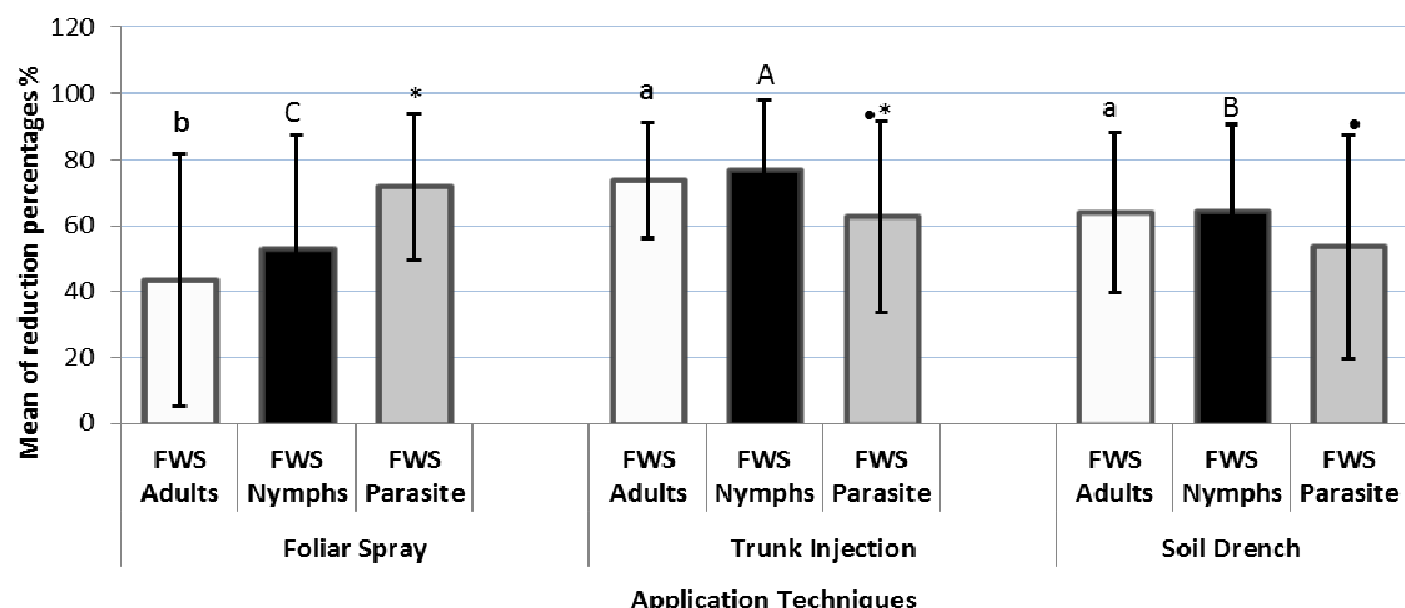

Fig. (4): The general means of reduction percentages of adults and nymphs of Florida wax scale (FWS) and its parasitoid by acetamiprid insecticide throughout different application techniques in the $2^{\text {nd }}$ season, 2020. F adult $=$ 15.185, df $=149$, L. S. D. $=11.05395 \mathrm{~F}$ nymphs $=9.191, \mathrm{df}=149, \mathrm{~L} . \mathrm{S} . \mathrm{D} .=11.04185 \mathrm{~F}$ parasite $=5.022, \mathrm{df}=149, \mathrm{~L}$. S. D. $=11.3292$

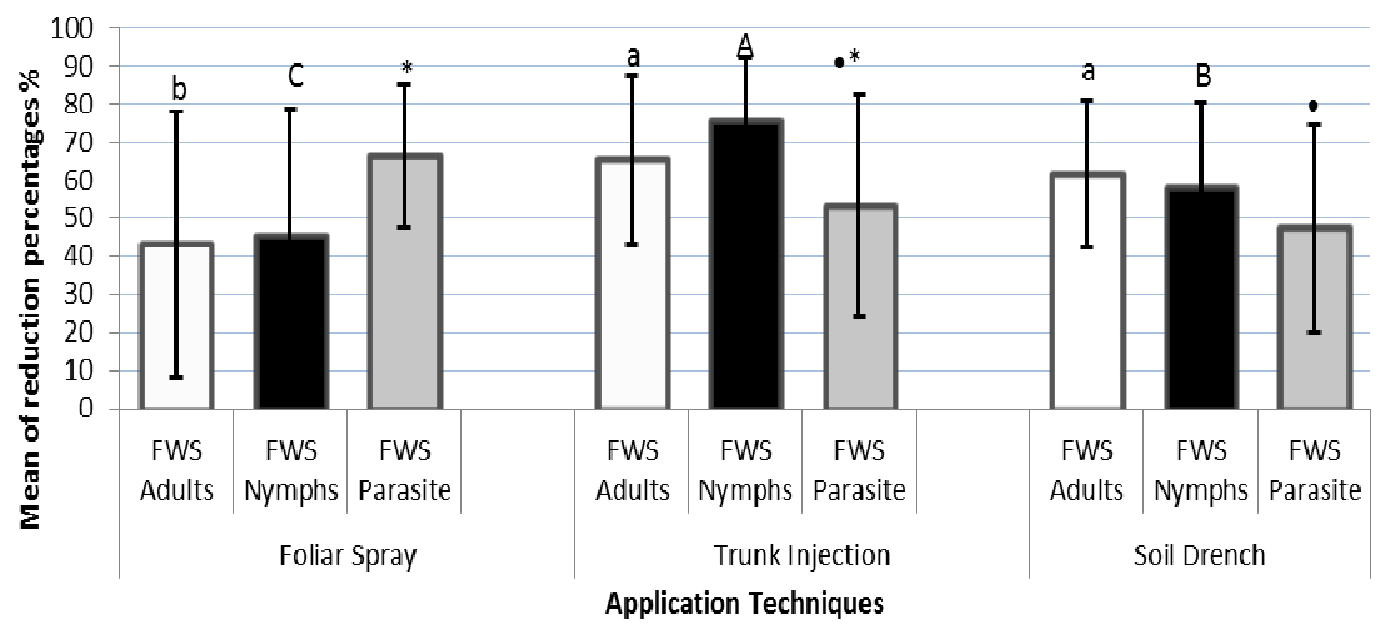

Fig. (5): The general means of reduction percentages of adults and nymphs of Florida wax scale (FWS) and its parasitoid by dinotefuran insecticide throughout different application techniques in the $1^{\text {st }}$ season, 2019. F adult $=$ 10.147, df = 149, L. S. D. = 10.3732; F nymphs =17.807, df =149, L. S. D. =9.9333; F parasite $=7.221$, df $=149$, L. S. D. $=10.06515$



Application Techniques

Fig. (6): The general means of reduction percentages of adults and nymphs of Florida wax scale (FWS) and its parasitoid by dinotefuran insecticide throughout different application techniques in the $2^{\text {nd }}$ season, 2020. F adult $=$ 16.186, df $=149$, L. S. D. $=10.1701 \mathrm{~F}$ nymphs $=13.937, \mathrm{df}=149$, L. S. D. $=10.1585 \mathrm{~F}$ parasite $=4.616, \mathrm{df}=149, \mathrm{~L}$. 


\section{Effect of the insecticides treatments:}

According to the general means of reduction percentages, the Florida wax scale populations were significantly reduced by the insecticide treatments (Figs. 7 and 8). Results indicated that, imidaclopride achieved the highest reduction $\%$ of adults and nymphs of $C$. floridensis with general mean $71.42 \%$ and $69.01 \%$ in $1^{\text {st }}$ season, $67.65 \%$ and $70.21 \%$ in $2^{\text {nd }}$ season, respectively. On the other hand, dinotefuran achieved the least reduction with general mean 56.61\% and $59.55 \%$ in $1^{\text {st }}$ season, $55.05 \%$ and $59.13 \%$ in $2^{\text {nd }}$ season. Imidaclopride gave the highest toxicity against parasite, C. scutellaris $(60.63 \%$ and $66.71 \%)$ followed by acetamiprid (57.53 and $62.59 \%$ ) which is followed by dinotefuran (55.53 and 58.79$)$ in $1^{\text {st }}$ and $2^{\text {nd }}$ season, respectively.

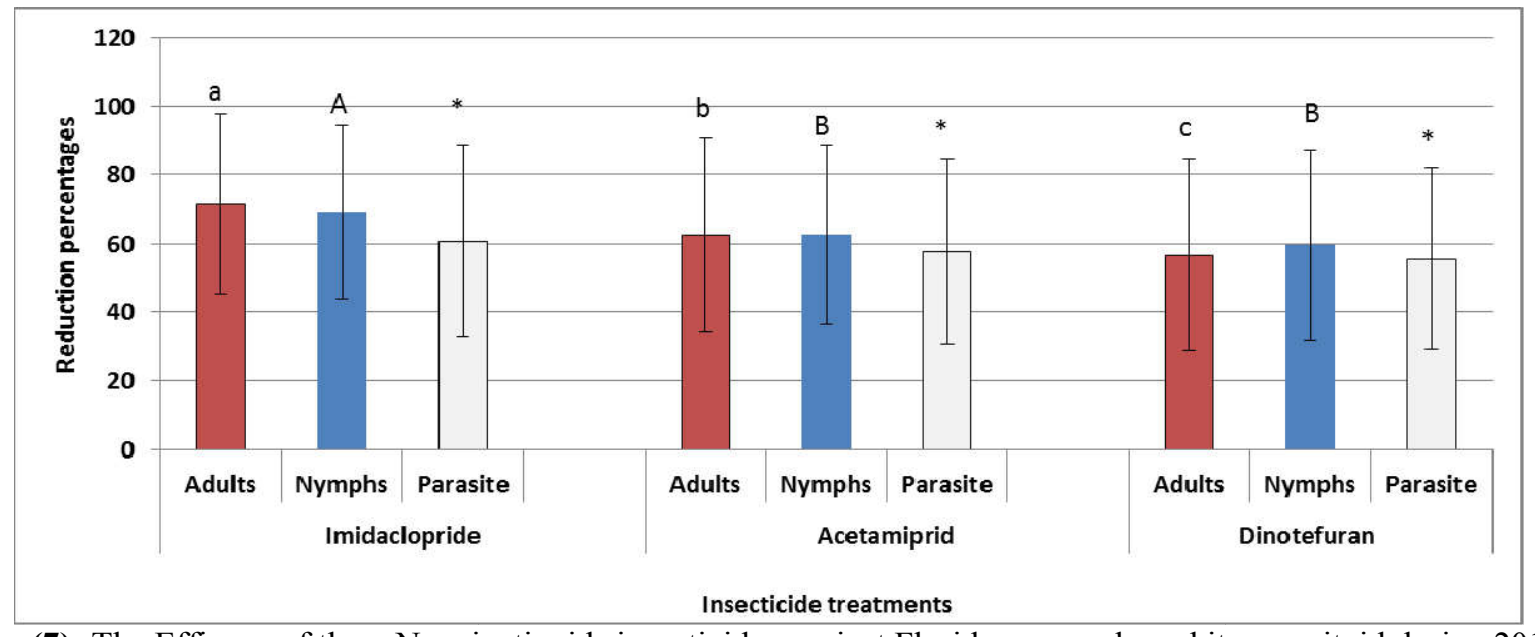

Fig. (7): The Efficacy of three Neonicotinoids insecticides against Florida wax scale and its parasitoid during 2019 season under field conditions as a general means of three different application methods. $\mathrm{F}$ adult $=11.125, \mathrm{df}=449, \mathrm{~L}$.

S. D. $=6.21555$. F nymphs $=4.978, \mathrm{df}=449$, L. S. D. $=6.00905$ F parasite $=1.341, \mathrm{df}=449$, L. S. D. $=6.16175$

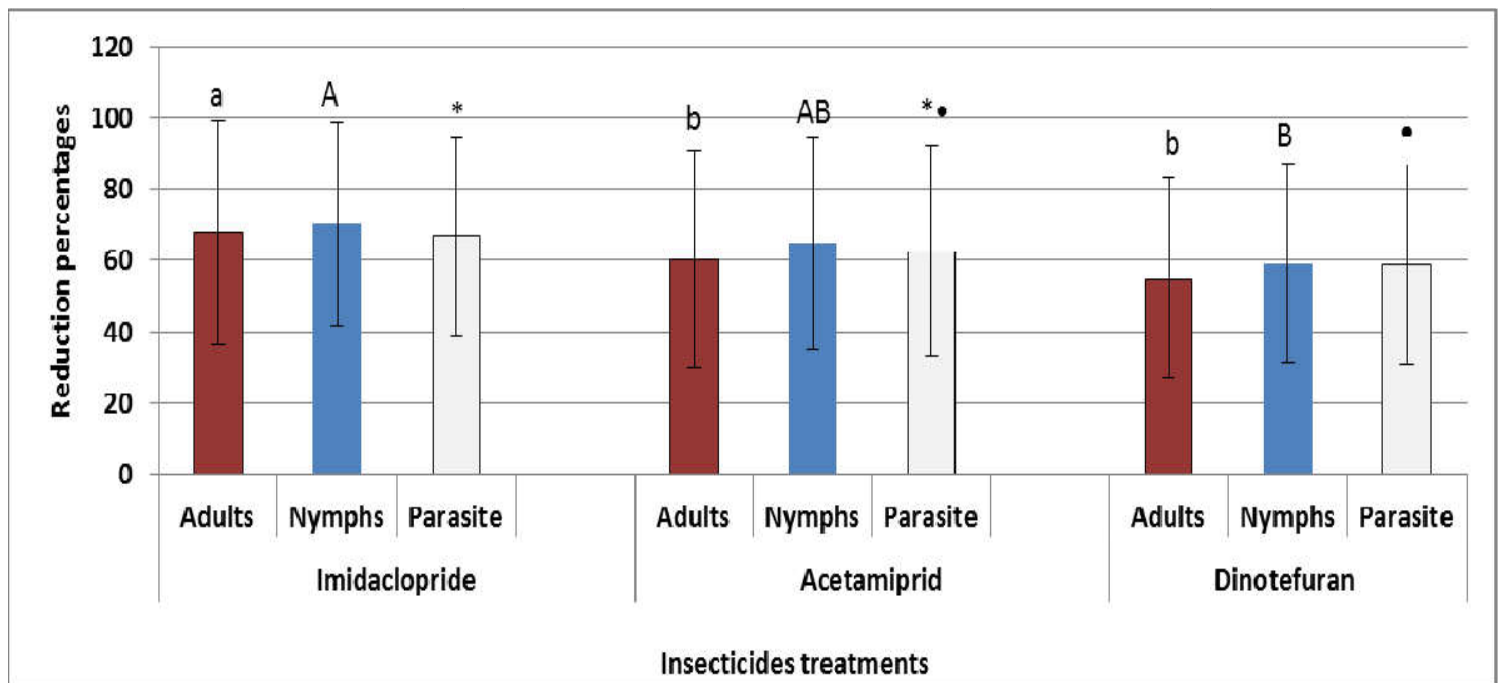

Fig. (8): The Efficacy of three Neonicotinoids insecticides against Florida wax scale and its parasitoid during 2020 season under field conditions as a general means of three different application methods. $\mathrm{F}$ adult $=6.635, \mathrm{df}=449, \mathrm{~L}$. $\mathrm{S}$. D. $=6.8271$. F nymphs $=5.622, \mathrm{df}=449$, L. S. D. $=6.49395$, F parasite $=2.931, \mathrm{df}=449$, L. S. D. $=6.427$

\section{Effect of the interactions between the application techniques and insecticides:}

There are many significant effects of the interactions among studied factors (application techniques and insecticides treatments) on studied characters. The three Neonicotinoids insecticides and the three types of application methods had significant differences between one of them with the other. Data presented in Tables 2 and 3 revealed that the best results of reduction percentages (highest percentages) of adults and nymphs of FWS obtained from samples treated with imidaclopride throughout trunk injection method. The least effective method was the foliar spray. In all cases of the foliar spray the nymphs of FWS were more affected by the three insecticides than the adults. On the contrary, the least suitable technique for the parasite of FWS was the foliar spray with imidaclopride insecticides which causing 70.91 and $72.09 \%$ reduction percentages in the 2019 and 2020 seasons, respectively. While the most suitable technique (the least reduction percentages) was achieved using the soil drench with the dinotefuran insecticide. 
Table (2): The general means of reduction percentages of adults and nymphs of Florida wax scale (FWS) and its parasitoid by three insecticide throughout three different application techniques in the $1^{\text {st }}$ season, 2019

\begin{tabular}{|c|c|c|c|c|}
\hline Application techniques & Insecticides & Adults of FWS & Nymphs of FWS & $\begin{array}{c}\text { The parasitoids, } C \text {. } \\
\text { scutellaris }\end{array}$ \\
\hline \multirow{4}{*}{ Foliar spray } & Imidaclopride & $54.26 \pm 30.93^{\mathrm{e}}$ & $57.54 \pm 33.03^{\mathrm{cd}}$ & $70.91 \pm 24.43^{\mathrm{a}}$ \\
\hline & Acetamiprid & $45.36 \pm 33.38^{f}$ & $49.87 \pm 35.21^{\mathrm{de}}$ & $68.1 \pm 23.71^{\mathrm{a}}$ \\
\hline & Dinotefuran & $43.12 \pm 34.79^{f}$ & $45.4 \pm 33.42^{\mathrm{e}}$ & $66.15 \pm 18.6^{\mathrm{ab}}$ \\
\hline & Mean & $47.58 \pm 33.2$ & $50.94 \pm 34.04$ & $68.39 \pm 22.33$ \\
\hline \multirow{4}{*}{ Soil drench } & Imidaclopride & $77.66 \pm 17.24^{\mathrm{ab}}$ & $69.84 \pm 21.32^{\mathrm{b}}$ & $53.72 \pm 29.03^{\mathrm{cd}}$ \\
\hline & Acetamiprid & $68.72 \pm 23.7^{\mathrm{cd}}$ & $62.02 \pm 17.83^{\mathrm{c}}$ & $48.91 \pm 21.747^{\mathrm{cd}}$ \\
\hline & Dinotefuran & $61.57 \pm 19.15^{\mathrm{de}}$ & $57.97 \pm 22.4^{\mathrm{c}}$ & $47.214 \pm 27.25^{\mathrm{d}}$ \\
\hline & Mean & $69.32 \pm 21.14$ & $63.28 \pm 21.06$ & $49.95 \pm 26.16$ \\
\hline \multirow{4}{*}{ Trunk injection } & Imidaclopride & $82.34 \pm 19^{a}$ & $79.64 \pm 12.49^{\mathrm{a}}$ & $57.25 \pm 27.65 b^{c}$ \\
\hline & Acetamiprid & $73.27 \pm 16.77^{\mathrm{bc}}$ & $76.03 \pm 13.51^{\mathrm{ab}}$ & $55.59 \pm 31.43^{\mathrm{cd}}$ \\
\hline & Dinotefuran & $65.15 \pm 22.12^{\mathrm{cd}}$ & $75.27 \pm 16.63^{\mathrm{ab}}$ & $53.23 \pm 29.27^{\mathrm{cd}}$ \\
\hline & Mean & $73.59 \pm 20.54$ & $76.98 \pm 14.35$ & $55.35 \pm 29.34$ \\
\hline L.S.D. & & 8.473 & 7.7751 & 9.4792 \\
\hline
\end{tabular}

In each column the mean followed by the same letter(s) are not significantly different as indicated by L.S.D. test (P=0.05)

Table (2): The general means of reduction percentages of adults and nymphs of Florida wax scale (FWS) and its parasitoid by three insecticide throughout three different application techniques in the $2^{\text {nd }}$ season, 2020

\begin{tabular}{|c|c|c|c|c|}
\hline Application techniques & Insecticides & Adults of FWS & Nymphs of FWS & $\begin{array}{c}\text { The parasitoids, } C \text {. } \\
\text { scutellaris }\end{array}$ \\
\hline \multirow{4}{*}{ Foliar spray } & Imidaclopride & $49.62 \pm 36.87^{\mathrm{e}}$ & $58.47 \pm 34.12^{\mathrm{de}}$ & $72.09 \pm 23.61^{\mathrm{a}}$ \\
\hline & Acetamiprid & $43.49 \pm 38.11^{\mathrm{ef}}$ & $52.75 \pm 34.64^{\mathrm{ef}}$ & $71.7 \pm 22.17^{\mathrm{a}}$ \\
\hline & Dinotefuran & $38.91 \pm 31.23^{\mathrm{f}}$ & $44.89 \pm 29.24^{\mathrm{f}}$ & $67.79 \pm 24.41^{\mathrm{ab}}$ \\
\hline & Mean & $44 \pm 35.56$ & $52.04 \pm 33.01$ & $70.53 \pm 23.34$ \\
\hline \multirow{4}{*}{ Soil drench } & Imidaclopride & $68.6 \pm 27.29^{b c}$ & $70.22 \pm 28.09^{\mathrm{bc}}$ & $59.14 \pm 33.6^{\mathrm{cd}}$ \\
\hline & Acetamiprid & $63.93 \pm 24.29^{\mathrm{cd}}$ & $64.43 \pm 26.22^{\mathrm{cd}}$ & $53.54 \pm 33.78^{\mathrm{d}}$ \\
\hline & Dinotefuran & $58.76 \pm 26.45^{\mathrm{d}}$ & $60.56 \pm 23.96^{\mathrm{de}}$ & $51.52 \pm 29.24^{\mathrm{d}}$ \\
\hline & Mean & $63.76 \pm 26.18$ & $65.07 \pm 26.27$ & $54.7315 \pm 32.22146$ \\
\hline \multirow{4}{*}{ Trunk injection } & Imidaclopride & $84.73 \pm 16.35^{\mathrm{a}}$ & $81.92 \pm 15.63^{\mathrm{a}}$ & $68.89 \pm 23.31^{\mathrm{ab}}$ \\
\hline & Acetamiprid & $73.69 \pm 17.45^{\mathrm{b}}$ & $76.7 \pm 21.31^{\mathrm{ab}}$ & $62.52 \pm 28.84^{\mathrm{bc}}$ \\
\hline & Dinotefuran & $67.47 \pm 17.64^{\mathrm{bc}}$ & $71.92 \pm 23.51^{\mathrm{bc}}$ & $57.07 \pm 27.77^{\mathrm{cd}}$ \\
\hline & Mean & $75.29 \pm 18.48$ & $76.85 \pm 20.69$ & $62.83 \pm 27.01$ \\
\hline L.S.D. & & 7.60983 & 8.78354 & 7.892 \\
\hline
\end{tabular}

In each column the mean followed by the same letter(s) are not significantly different as indicated by L.S.D. test (P=0.05)

\section{DISCUSSION}

Results of the current study revealed significant differences in the reduction percentages (mortality) of FWS, C. floridensis and its parasitoid, $C$. scutellaris between the different application techniques and insecticide treatments in all sampling sessions. By this study, we compared the efficiency of three different application methods comprised of foliar spray, trunk injection and soil drench against FWS and it parasitoid. The results revealed a high efficacy of the trunk injection and soil drench in suppressing FWS population which agrees with findings of Bhandari and Cheng (2016) for control stem and leaf gall wasps, Josephiella species (Hymenoptera: Agaonidae), on Chinese banyan. The results also are in agreement with Arbab Tafti et al. (2014) on the high efficacy of trunk injection in control of Dubas bug, Ommatissus lybicus (Hemiptera: Tropiduchidae) on date palms. Additionally, the results also refer to fewer side effects of trunk injection and soil drench on the parasite, $C$. scutellaris compared with foliar application may be due to the less direct contact. Similar results were obtained by many other studies such as Arbab Tafti et al. (2014) who found fewer side effects of trunk injection on natural enemies of $O$. lybicus on date palms compared with foliar application. Also, the results of Wise (2014), Paula Alayón Luaces et al. (2018), Majeed Askari Seyahooei (2019) and Darwish (2020) refer to the use of trunk injections and soil drench would be a more efficient and more environmentally friendly than the foliar spray method. They concluded that the use of trunk injection and soil drench reduces the drift of insecticides and environmental risks and consequently also safe for farmers, agricultural workers. In this study we test three of the neonicotinoid insecticides viz. acetamiprid, dinotefuran and imidaclopride. Fernandes de Cordova and Gallego (1997) cured the oak sale insect which infested oak trees by injection the trees with imidacloprid solution; moreover, they added that more 
than $79 \%$ control of this insect was obtained when imidacloprid was injected at rates of $0.8 \mathrm{ml}$ per tree. The results also are consistent with Paula Alayón Luaces et al. (2018) who reported that to control the snow scale of citrus trunk under the field conditions only one application of imidacloprid injections per campaign is enough. The least effective insecticide was dinotefuran, especially when applied as a foliar spray. It achieved only 43.12 and $45.4 \%$ reduction percentages in the $1^{\text {st }}$ season and 38.91 and $44.89 \%$ in the $2^{\text {nd }}$ season for adults and nymphs of FWS, respectively. Quesada et al. (2018) fount that the insecticide dinotefuran was non effective (as a foliar spray) on the two soft scale insects, calico scale (Eulecanium cerasorum) and striped pin scale (Toumeyella pini). While this insecticide was effective when applied as a soil drench against the soft scale, Eulecanium cerasorum (Quesada Machigua, 2013).

\section{REFERENCES}

Abd-Rabou, S. (2001). Parasitoids attacking soft scales (Homoptera: Coccidea) in Egypt," Egyptian Journal of Agricultural Research, 79(3): 859-880. https://agris.fao.org/agrissearch/search.do?recordID=EG2004000966

Abo-Shanab, A. S. H. (2012). Suppression of white mango scale Aulacapsis tubercularis (Hemiptera: Diaspididae) on mango trees in EL-Beheira Governorate. Egypt. Egypt. Acad. Biol. Sci., 5(3): 43-50

https://eajbsa.journals.ekb.eg/article_13870.html

Arbabtafti, R., A. Sheikhigarjan, A. H. Gharalari and R. Damghani (2014). Effects of adjuvants on the efficacy of certain insecticides against Ommatissus lybicus Bergevin (Hem.: Tropiduchidae) in Iran. Jordan Journal of Agricultural Sciences, 10: 526-533. https://journals.ju.edu.jo/JJAS/article/view/7 224

Ben-Dov, Y. (1993). A systematic catalogue of the soft scales of the World (Homoptera: Coccidea: Coccidae) with data on geographical distribution, host plants, biology and economic importance. Flora and Fauna Handbook No. 9., Sandhill Crane Press, Inc. Gainsville, Florida, $536 \quad$ pp. https://www.cabi.org/isc/abstract/199511029 07

Bhandari, B. P. and Z. Cheng (2016). Trunk injection of systemic insecticides to control stem and leaf gall wasps, Josephiella species (Hymenoptera: Agaonidae), on Chinese banyan (Rosales: Moraceae) in Hawaii. Florida Entomologist, 99(2): 172-177. DOI: 10.1653/024.099.0203

Darwish, A.A.E. (2020). Performance of Aphytis lepidosaphes Compere as a Biological Control Agent of Lepidosaphes beckii (New.). Journal of Entomology, 17(1): 2735. DOI: $10.3923 /$ je.2020.27.35

Doccola, J. J. and P. M. Wild (2012). Tree injection as an alternative method of insecticide application, pp. 61-78 In Soloneski S, Larramendy $\mathrm{M}$ [eds.], Insecticides-Basic and Other Applications. InTech, Rijeka, Croatia. DOI: $10.5772 / 29560$

Doccola, J. J., S. L. Smith, B. L. Strom, A. C. Medeiros, E. von Allmen (2009). Systemically applied insecticides for treatment of erythrina gall wasp, Quadrastichus erythrinae Kim (Hymenoptera: Eulophidae). Arboriculture and Urban Forestry 35: 173-181. https://www.fs.usda.gov/treesearch/pubs/334 53

Eserkaya, E. and I. Karaca (2016). Population Development of Ceroplastes floridensis on Grapefruit and Oranges. Asian Journal of Agriculture and Food Sciences, 4(2): 60-65. https://ajouronline.com/index.php/AJAFS/art icle/view/3612

Elekcioğlu, N. Z. and D. Şenal, (2007). Pest and Natural Enemy Fauna in Organic Citrus Production in East Mediterranean Region of Turkey, International Journal of Naturel and Engineering Sciences, 1, 29-34.

Fernandez de Cordova, J. Y and F. J. Gallego, (1997). Control of the oak scale Astrolecanium iticicola Targ. by injection of insecticide into the tree trunk. Boletin de Sanidad - Vegetal Plagas 23(4): 607-661 (in Spanish, English abstract)

Gomez, K. A. and A. A. Gomez (1984): Statistical Procedures for Agricultural Research. $2^{\text {nd }}$ Ed., Jhon Wiley and Sons Inc., New York, pp: 95-109. https://pdf.usaid.gov/pdf_docs/PNAAR208.p df

Henderson, C. F. and E. W. Tilton (1955). Tests with Acaricides against the Brown Wheat Mite 12. Journal of Economic Entomology. 48(2): 157-61. doi:10.1093/jee/48.2.157. DOI: 10.21608/eajbsf.2019.31760

Majeed Askari Seyahooei, Abdoolnabi Bagheri, Sohrab Morshedi, Majid Fallahzadeh, Sareh Amiri and Maryam Shahi (2019). Trunk Injection a Promising Approach for LongLasting Suppression of Mango Leaf Hopper, Idioscopus clypealis Egypt. Acad. J. Biolog. Sci. (F. Toxicology \& Pest control), Vol. 11(1): 123-129. DOI: 10.21608/eajbsf.2019.31760

Nikol'skaja, M. N. (1952). The chalcidoid fauna of the USSR: opred. Faun," Trudy Zo ologicheskogo Instituta Akademii Nauk SSSR, vol. 44, p. 575 (Russian). https://www.cabi.org/ISC/abstract/20057007 689

Norris, D. M. (1965). Systemic pesticides in woody plants: uptake. Bulletin of the Entomological Society of America, 11: 187-190. https://doi.org/10.1093/besa/11.3.187a

Paula Alayón Luaces, Laura I. Giménez Ojeda, Marco D. Chabbal Monzón, Silvia M. Mazza Jeandet and Víctor A. Rodríguez Da Silva 
Ramos (2018). Imidacloprid injections effectiveness for control of snow scale of citrus trunk. Cultivos Tropicales, 39(1): 1520

https://www.cabdirect.org/cabdirect/abstract/ 20183313452

Perry, T. O., J. r. Santamour, F. S., R. J. Stipes, T. Shear and A. L. Shigo, (1991). Exploring alternatives to tree injection. Journal of Arboriculture, 17: 217-226. https://scinapse.io/papers/175623611

Quesada Machigua and Carlos Roberto (2013). Effects Of Selected Pesticides On Calico Scale And Its Natural Enemies. Open Access Theses. 132.

https://docs.lib.purdue.edu/open_access_thes es/132

Quesada, C. R., A. Witte and C. S. Sadof (2018). Factors influencing insecticide efficacy against armored and soft scales. HortTechnology, 28: 267-275. https://doi.org/10.21273/HORTTECH0399318

Radwan, S. (2003): Toxicological studies on some scale insects infesting mango and guava trees. Ph. D. Thesis, Fac. Agric. Cairo Univ., 221 pp. DOI: 10.21608 /eajbsa.2012.14261

Rosen, D. (1967): The hymenopterous parasites of soft scales on citrus in Israel, Beiträge Zur Entomologie, 17(1-2): 251-279. DOI:10.21248/contrib.entomol.17.1-2.251279

Snedecor, G. W. and W. G. Cochran (1980). Statistical Methods. $7^{\text {th }}$ Ed. Iowa State University Press, Iowa, USA., PP. 507. https://www.amazon.com/Statistical-
Methods-Seventh-isbn0813815606/dp/B0012S4NIE

Siam A. and E. Othman (2020). Field evaluation of botanicals extracts for suppressing the mango scale insect, Aulacaspis tubercularis (Newstead) (Hemiptera: Diaspididae). Egyptian Journal of Biological Pest Control, 30(22): 1-5. https://doi.org/10.1186/s41938020-00221-4

VanWoerkom, A. H. (2012). Trunk Injection: A new and innovative technique for pesticide delivery in tree fruits. MSc thesis, Michigan State university. East lansing, MI, USA. https://d.lib.msu.edu/etd/516/datastream/OBJ /download/Trunk_injection_a_new_and_i nnovative_technique_for_pesticide_delivery in_tree_fruits.pdf

Wise, J. C., A. H. VanWoerkom, S.G. Aćimović, G. W. Sundin, B. M. Cregg and C. Vandervoort (2014). Trunk Injection: A Discriminating Delivering System for Horticulture Crop IPM. Entomology, Ornithology \& Herpetology, 03(02): 126. doi:10.4172/21610983.1000126.

Zaki, A. M., H. M. El-Sharkawy, F. S. El-Santil and Nahla A. Ezz (2019). Ecological studies on Ceroplastes floridensis (Hemiptera: Coccidae) infesting two varieties of orange trees at Sharkia Governorate, Egypt. J. Product. \& Dev., 24(1): 63 - 75. DOI: 10.21608/jpd.2019.41322

Zhu, H., R. C. Derksen, H. Guler, C. R. Krause and H. E. Ozkan (2006). Foliar deposition and offtarget loss with different spray techniques in nursery applications. ASABE, 49: 325-334. https://link.springer.com/article/10.1186/s41 938-020-00221-4

\section{تقييم كفاعة طرق تطبيق مختلفة لثلاث مبيدات نبكوتينية مختلفة علي حشرة الموالح الثمعية Coccophagus scutellaris والطقيل الخاص بكان Ceroplastes floridensis}

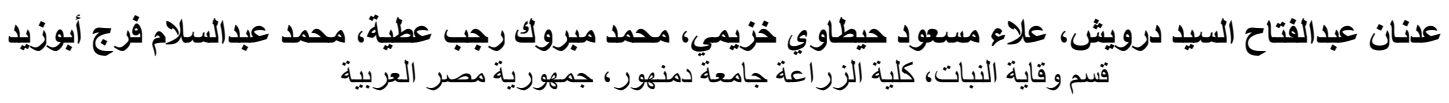

تعتبر حشرة الموالح الثمعية Ceroplastes floridensis واحده من أهم الآفات الحشرية التي تصيب أثجار الموالح في العالم.

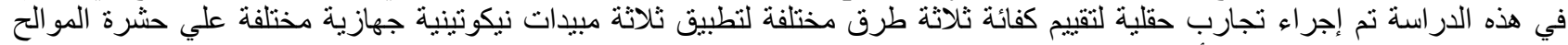

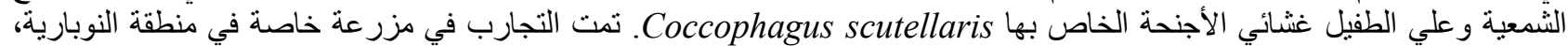



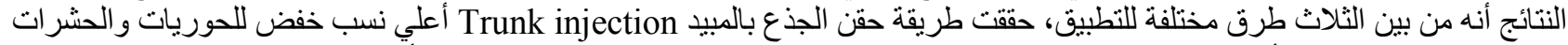

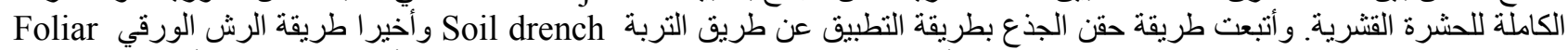

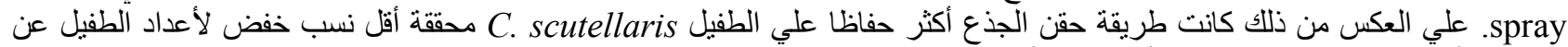

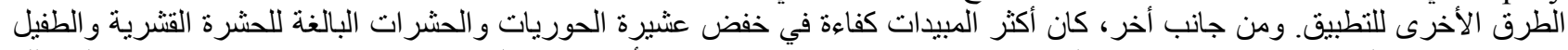

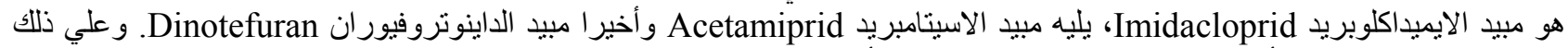

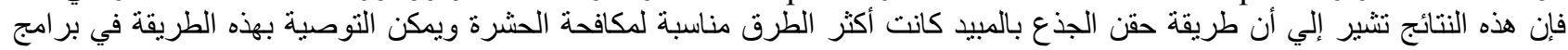

